\title{
Zoriana Rybczyńska
}

Narodowy Uniwersytet Lwowski im. Iwana Franki

\section{Aktywizm miejski i nowe rozumienie kultury. Przyczynek do badań miejskich na Ukrainie i Białorusi}

Abstrakt: W artykule przedstawiona została na rozmaitych przykładach działalność aktywistów miejskich, ich główne przedmioty i metody działan. Omówione zostały problemy występujące w tym zakresie na Ukrainie i Białorusi. Jednocześnie, na podstawie tej analizy, autorka próbuje odpowiedzieć na wiele pytań: o to, gdzie dziś lokowana jest kultura, o jej twórców, o polityki miejskie i strategie retoryczne określające kulturę i wreszcie, jak współczesne praktyki aktywizmu miejskiego oddziaływają na pojmowanie kultury jako całości.

Słowa klucze: aktywizm miejski, urbanizm, polityki miejskie, partycypacja, wspólnoty lokalne, kultura uczestnictwa, miasto

Historia aktywizmu miejskiego jest związana ze zmianą myślenia o mieście w kontekście ponowoczesności. Wśród wielu tekstów poświęconych temu tematowi ważna jest książka Henriego Lefebvre'a Prawo do miasta ${ }^{1}$ z 1968 roku, dzięki której tytułowe hasło określiło wspólny obszar idei dotyczących różnorodnych ruchów społecznych i trendów intelektualnych zorientowanych na nowe myślenie o mieście, miejskości oraz strategiach i praktykach kulturowych z nimi związanych. Od czasu ukazania się książki Lefebvre'a urbanistyka z dyscypliny specjalistycznej przekształciła się w interdyscyplinarne urban studies, a ruchy społeczne w nowy rodzaj uczestniczenia w kulturze - aktywizm miejski, który nie da się określić jedną definicją. Jeżeli jednak spróbować znaleźć podstawowe określenie ruchów miejskich, to na pewno warto przede wszystkim ujawnić przesłanki ich pojawienia się, wśród których chyba najważniejszy jest kryzys nowoczesnej koncepcji miasta. Nie może już ono zaspokoić potrzeb mieszkańców, a władze zajmujące się planowaniem środowiska miejskiego nie są w stanie usprawnić działania dóbr publicznych. Często więc u źródeł ruchów miejskich

${ }^{1}$ H. Lefebvre, Prawo do miasta, „Praktyka Teoretyczna” 2012, nr 5, http:// www.praktykateoretyczna.pl/PT_nr5_2012_Logika_sensu/14.Lefebvre. pdf [dostęp: 15 listopada 2015]. 
stoi niezadowolenie lub protest przeciw polityce miejskiej. Oprócz tego aktywizm można potraktować jako osobliwy sposób komunikacji, prowokujący próby ulepszania otaczającej rzeczywistości, to znaczy bezpośredniego uczestniczenia w kulturze. Przez to środowisko (kultura), w którym działa człowiek, staje się coraz bardziej dynamiczne, dialogiczne, atrakcyjne.

Lokalne władze miast poradzieckich na Białorusi i Ukrainie traktują problemy związane z transportem, komunikacją oraz infrastrukturą mieszkaniowo-usługową w sposób technokratyczny. Już pierwsze próby analizy rozwoju tychże miast, jak twierdzą urbaniści ${ }^{2}$, prowadzą do niezbyt optymistycznych wniosków: środowisko nieprzyjazne, infrastruktura stara i niewygodna, w tym wszystkim wyalienowany człowiek. Materialna tkanka miasta odzwierciedla jego strukturę społeczną. Przy takim założeniu bardziej zrozumiałe wydają się choćby próby grodzenia poszczególnych terenów miejskich, świadczące o wzajemnej nieufności mieszkańców, czy zaniedbane podwórka, będące wyrazem braku wspólnot lokalnych. Modernistyczna tradycja, zwłaszcza w radzieckim wydaniu, wmontowała (przeważnie skutecznie) zarówno w przestrzeń nowo stworzonych, jak i starych miast całkowitą hierarchię zarządzania, w wyniku czego po transformacji ustrojowej z pola widzenia zniknęli ludzie, rozumiani jako podmiot zmiany. W tym sensie jeszcze parę lat temu można było powiedzieć, że na Ukrainie i Białorusi nie ma żadnego miasta, jeżeli kojarzyć z nim wspólnotę miejską decydującą o wyglądzie miasta, o tym, co się w nim dzieje, czym ono żyje. Sytuacja ulega zmianie, choć bardzo powoli i jeszcze nie radykalnie: w ostatnich latach na fali hipsterskiej mody młodzieżowej na Białorusi i Ukrainie pojawiły się rozmaite ruchy miejskie będące odmianą kulturowej alternatywy czy nawet politycznej opozycji. Aktywiści zaczęli sami zajmować się porządkowaniem miast, tworzeniem nowych przestrzeni publicznych, wypełnianiem ich wydarzeniami kulturowymi: koncertami, festiwalami kina na wolnym powietrzu, degustacjami kulinarnymi. Wydawało się, że to tylko nowy, „modny” format rozrywki młodzieżowej, jednak już w 2012 roku wiele wydarzeń potwierdziło powagę zamiarów aktywistów: zaczęli walczyć o ocalenie zabytkowych bu-

${ }^{2}$ Więcej о tym: Місто й оновлення. Урбаністичні студї, Представництво Фонду ім. Гайнріха Бьолля в Украӥні, red. С. Шліпченко et al., Київ 2013; В. Тыминский, Постсоветский город: проблемы и принципь проектирования будущего = Postsoviet city: problems and principles of future's creating, [w:] Совершенствование организации дорожного движения и перевозок пассажсиров и грузов, red. Ф. Романюк, Минск 2014, s. 317-324; R. Balokaite, Post-Soviet Transitions of the Planned Socialist Towns: Visaginas, Lithuania, „Studies of Transition States and Societies" 2, 2010, nr 2, s. 63-81; Ch. Bernhardt, Planning Urbanization and Urban Growth in the Socialist Period: The Case of East German New Towns, 1945-1989, „Journal of Urban History” 32, 2005, s. 104-119; A. Finogenov, Modern Russia and Urban-Planning Reality of Post-Soviet City, http://urbanica.spb.ru/?page_id=645\&lang=en [dostęp: 15 listopada 2015]; J. Robinson, Soviet city: identity and community development, https:/www.researchgate.net/publication/255616367_THE POST-SOVIET_CITY_IDENTITY_AND_COMMUNITY_DEVELOPMENT [dostęp: 15 listopada 2015]; The post-socialist city: Urban form and space transformations in Central and Eastern Europe after Socialism, red. K. Stanilov, Dordecht 2007. 
dowli, reanimować biblioteki i domy kultury na osiedlach, ratować zagrożone przez deweloperów parki ${ }^{3}$. W trakcie przygotowania i realizacji tych bardzo różnych wydarzeń i projektów rozwinęły się rozmaite formy samoorganizacji, oporu przeciw władzom. To doświadczenie okazało się bardzo potrzebne, a nawet niezbędne na Ukrainie, zwłaszcza podczas wydarzeń na Majdanie w Kijowie od listopada 2013 do lutego 2014 roku. Był to punkt zwrotny nie tylko dla życia politycznego Ukrainy (i częściowo Białorusi), lecz także dla rozwoju ruchów miejskich. W ciągu ostatnich dwóch lat trudno znaleźć w tych krajach większe miasto, w którym spontanicznie nie powstawałyby ,inicjatywy miejskie”, włączone w fundamentalną walkę o ,prawo do miasta". Oczywiście ze względu na system polityczny na Białorusi walka ta jest ukryta, a w działaniach kulturowych i wspólnotowych zamaskowana w radzieckiej nowomowie pod hasłem „,solidarności wszystkich pracowników”, „samodiejatelnosti" itp.

Jednak mimo oczywistej i już bardzo odczuwalnej obecności aktywizmu miejskiego, nadal pozostaje problem z jego definicją. Oto kilka przykładów z różnych ukraińskich i białoruskich portali internetowych, próbujących określić to zjawisko ${ }^{4}$ :

— oddolna aktywność zmierzająca do włączenia mieszkańców w zarządzanie miastem z zamiarem przedefiniowania panujących stosunków ${ }^{5}$;

— oddolne ruchy stawiające sobie za cel modyfikację otaczającej nas miejskiej przestrzeni, poprawę jakości życia czy ochronę zabytków albo zieleni6;

- działanie publiczne mające na celu obronę praw upośledzonych grup społecznych, uczestniczenie poszczególnych jednostek w społecznie ważnych działaniach: uporządkowanie terytorium, bezpieczeństwo na drogach, zbiórka pieniędzy na rzecz rozwiązania problemów domu, dzielnicy ${ }^{7}$.

Jak widać, miejski aktywizm przybiera różne formy i nie ma wspólnego horyzontu celów, a jednak przy dokładniejszym spojrzeniu można zauważyć swoistą wspólnotę wartości, wyrażającą się w aktywistycznych hasłach manifestów:

— mieszkańcy miasta nie są obojętni na poczynania władz i swoje otoczenie;

- uporządkowanie miejskiej przestrzeni, ukrócenie samowoli deweloperów i mieszkańców, zapanowanie nad niekontrolowanymi zmianami układu przestrzennego i wizualnego;

3 Na przykład park Gorkiego w Charkowie, aleja Pejzażowa i Republika Kulturowa „Hostynnyj dwir” w Kijowie, obywatelski ruch „Zwolni drogę!” i projekt „Biblioteka na osiedlu” we Lwowie, galeria ,y̆” i festiwal na Gruszewce w Mińsku.

${ }^{4}$ Wykorzystanie zródeł internetowych w poszukiwaniu definicji aktywizmu miejskiego jest związane przede wszystkim z tym, że wiekszość publikacji na ten temat na Ukrainie i Bialorusi ukazuje się właśnie na rozmaitych portalach środowiskowych. Natomiast poważniejsze rozwiązania akademickie są tylko w przygotowaniu.

${ }^{5} \mathrm{http} / / /$ studway.com.ua/urban-iniciativi [dostęp: 15 listopada 2015].

${ }^{6} \mathrm{http}: / /$ urbanist.by/ [dostęp: 15 listopada 2015].

${ }^{7} \mathrm{http}: / /$ spilnorivne.tumblr.com [dostęp: 15 listopada 2015]. 
— alternatywa urzędniczej niekompetencji i marazmu, tyranii inwestorów oraz wszechobecnego niedbalstwa i brzydoty;

- autentyczny obywatelski głos, powiew alternatywnego i ożywczego spojrzenia na miasto;

— i może nawet (czemu nie pomarzyć?) przejaw „klasowej świadomości młodej klasy średniej".

Wydaje się, że bardziej skuteczne będzie określenie tego zjawiska nie na podstawie jego definicji, lecz raczej obserwacji działań, to znaczy sposobów i form uczestniczenia aktywistów i mieszkańców w życiu miasta jako podstawowym miejscu tworzenia i konsumpcji dóbr kulturowych. Właśnie taką interesującą próbę diagnozy można znaleźć na stronie internetowej litewskiej interdyscyplinarnej platformy Laimikis.lt, jednoczącej badaczy miasta, wspólnoty artystyczne i społeczne inicjatywy, zajmujące się nieformalną edukacją i aktywizmem ${ }^{8}$. Co-urbanism map ${ }^{9}$ była stworzona w ramach wspólnego projektu litewskiej Laimikis.lt oraz „Mińskiej platformy urbanistycznej” (Białoruś) jako instrument do zbierania i analizy przykładów i metod praktykowania uczestnictwa (partycypacji). Mapa przedstawia nie tylko zestaw metod wykorzystywanych przez aktywistów miejskich w budowaniu i aktywizacji lokalnej współpracy i solidarności. Prezentuje również pracujące z nimi grupy, jest także instrumentem analitycznym identyfikującym problemy miejskie i sposoby ich rozwiązań w różnych regionach. Mapa ma charakter interaktywny i otwarty, a organizatorzy zapraszają do przyłączenia się i przedstawienia swoich problemów, metod ich rozwiązań. Według niej dwoma głównymi przedmiotami aktywności ruchów miejskich pozostają przestrzeń publiczna i wspólnota lokalna. Właśnie w połączeniu tych kategorii ujawniają się podstawowe relacje między miejscem i ludźmi, tak ważne dla ruchów miejskich. Te relacje dobrze wpisują się również w kategorie krajobrazu kulturowego, którego teoretyczne opracowanie $\mathrm{w}$ bardzo interesujący sposób przejawia się $\mathrm{w}$ strategiach i taktykach miejskich. Najbardziej popularnymi metodami pracy wśród aktywistów miejskich są festiwale, wydarzenia edukacyjne i zagospodarowywanie terenu. Na Ukrainie przed 2013 rokiem częściej stosowane były occupation tactics, jednak coraz bardziej zauważalny jest wzrost partycypacyjnego projektowania i interwencji artystycznych. W obu krajach dostrzec można próby kontrolowania tych działań zarówno przez władzę (zwłaszcza na Białorusi), jak i przedstawicieli różnych firm sieciowych lub korporacji (nierzadko na Ukrainie). $\mathrm{Na}$ Białorusi jednak na razie podporządkowanie się władzom jest jedynym sposobem działań aktywistów. W trakcie realizacji swoich projektów aktywiści w pewnym momencie stają przed koniecznością formułowania ważnych dla nich kategorii. Przyjrzyjmy się bliżej kilku projektom, ich taktykom i zapleczu ideowemu.

\footnotetext{
${ }^{8} \mathrm{http} / / /$ laimikis.lt [dostęp: 15 listopada 2015].

${ }^{9}$ A Map of Urban Initiatives, https://kumu.io/UrbanMap/co-urbanism [dostęp: 10 listopada 2015].
} 
Ruch Дайте пройти! (Zwolnijcie drogę!) ${ }^{10}$ jednoczy aktywnych obywateli, którzy chcą mieszkać w bezpiecznych i komfortowych miastach. Aktywiści ruchu występują o prawo mieszkańców do miasta, bronią praw pieszych przed natłokiem innych uczestników ruchu drogowego. Dla nich więc przestrzeń wspólna, publiczna to głównie miejsce poruszania się, gdzie różne grupy mieszkańców deklarują i bronią swoich praw, wchodzą w interakcje z tymi, którzy je naruszają. W taki sposób dowodzą bierności miejscowych władz i biorą na siebie odpowiedzialność za miasto. Ten zapoczątkowany w 2012 roku we Lwowie ruch obejmuje teraz już około dziesięciu miast i nastawiony jest na polemikę z władzami. Włączenie nowych członków to ich własna decyzja, powodowana nieobojętną postawą obywatelską i gotowością do konfrontacji z innymi grupami. Podobne zasady występowania przeciw władzom i spontanicznego formowania grup inicjatywnych można zobaczyć w wypadkach walki o przestrzenie publiczne traktowane jako zabytki kultury, historyczne. Najbardziej znane na Ukrainie są dwa przykłady. Pierwszy z nich to walka o zachowanie gmachu Dworu Hostynnego w Kijowie w latach 2012-2013. Zastosowano tu taktykę protestów, a potem okupacji budowli mającej status zabytku, którą władze miejskie postanowiły przebudować na dom towarowy. Przez parę miesięcy funkcjonowała Republika Hostynna łącząca aktywistów, artystów i ekspertów, działająca w formie otwartego uniwersytetu z licznymi wydarzeniami edukacyjnymi i artystycznymi. W końcu doszło do starć z władzami, spacyfikowania i aresztowania aktywistów, rozpoczęto też prace budowlane. Do dziś budynek Dworu Hostynnego stoi niezagospodarowany w stanie niezakończonej przebudowy, ale aktywiści nie dają za wygraną - osiągnęli cel: przywrócenie budowli statusu zabytku narodowego. Zbierają również podpisy pod petycją o przekazanie jej Uniwersytetowi Narodowemu - Akademii Kijowsko-Mohylańskiej. Inny przykład pochodzi ze Lwowa i jest związany z zamiarem rekonstruowania przez władze miejskie w 2015 roku placu Świętego Jura i postawienia tam pomnika Andreja Szeptyckiego. W wyniku tej rekonstrukcji miał zniknąć zabytkowy skwer zaprojektowany w końcu XIX stulecia przez Arnolda Röhringa, naczelnego ogrodnika miasta i autora parku Stryjskiego - dziś to zaniedbana, ale ważna dla mieszkańców przestrzeń publiczna. Burzliwe dyskusje z władzami, autorami projektu i przedstawicielami Kościoła greckokatolickiego ujawniły konflikty związane przede wszystkim z niezdolnością władz do przeprowadzenia otwartej i uczciwej dyskusji publicznej z konserwatywnym Kościołem i liberalnie nastawionymi środowiskami aktywistów miejskich. Oprócz taktyk okupacyjnych i interwencji artystycznych aktywiści celowo zajęli się włączeniem do dyskusji mieszkańców z okolic tego placu, demonstrując dużo lepsze zdolności do negocjacji niż Kościół czy władze miejskie. Wśród głównych haseł ich manifestu było żądanie wprowadzenia skutecznych mechanizmów realizacji prawa społeczności do wpływu na decyzje o kształtowaniu przestrzeni publicznych

${ }^{10} \mathrm{http}: / /$ www.trotuar.lviv.ua/ [dostęp: 10 listopada 2015]. 
w mieście. W końcu skwer udało się zachować (czeka teraz na odnowienie), natomiast część placu została przebudowana, a pomnik uroczyście odsłonięty przez prezydenta Ukrainy i metropolitę Kościoła greckokatolickiego.

Jak pokazują wspomniane tu przypadki, działanie w historycznych centrach miast często prowokuje poważne konflikty między mieszkańcami a władzami i developerami (te ostatnie przeważnie są ze sobą powiązane). Niestety na Ukrainie, a tym bardziej Białorusi, trudno znaleźć przykłady udanego ich rozwiązania, albowiem władze najczęściej dokonują manipulacji i przejawiają niechęć do dialogu. Natomiast bardziej skuteczne okazują się działania aktywistów miejskich w okolicach i osiedlach oddalonych od centrum. Przykładem takiej udanej inicjatywy może być utworzenie skweru Godności na lwowskim osiedlu Sychiw, która połączyła miejscowych mieszkańców, interdyscyplinarną inicjatywę urbanistyczną Grupa 109 założoną przez kilkoro członków Ośrodka Ruchu Miejskiego Łypnewa. Gdy miejscowy przedsiębiorca zdecydował się zbudować dom towarowy na placu między budynkami mieszkalnymi i szkołą, aktywiści zjednoczyli się w organizację pozarządową Lepszy Sychów ${ }^{11}$. Cel został osiągnięty: założono tu skwer Godności sfinansowany ze środków miejscowego budżetu. Wspólnie przygotowano projekt i latem 2015 roku już rozpoczęły się prace. $U$ podstaw takich działań leży wypracowana strategia uwzględniająca potrzebę współpracy z miejscową wspólnotą, kształtowania i realizowania nowych wartości związanych z myśleniem o przestrzeni jako ważnym elemencie środowiska miejskiego oddziałującego na tożsamość wspólnotową, politykę publiczną, wreszcie na tworzenie mocnych poziomych relacji społecznych. Te ostatnie stają się osobnym przedmiotem zainteresowania wielu inicjatyw miejskich zorientowanych przede wszystkim na działanie ze społecznościami lokalnymi.

Jeden z pierwszych takich przykładów znów pochodzi ze Lwowa i związany jest $\mathrm{z}$ reanimacją biblioteki na oddalonym od centrum osiedlu Zboiszcza. Inicjatorem był mieszkaniec, ojciec trójki dzieci, który zorientował się, że w ich dzielnicy nie ma miejsca, które byłoby otwarte dla wszystkich. Natomiast jest niewielka biblioteka $\mathrm{nr} 37$, istniejąca jeszcze od czasów radzieckich i z każdym rokiem coraz bardziej upadająca. W sąsiedztwie było kilka zainteresowanych osób, z którymi wspólnie zaczął urządzać w bibliotece różne przedsięwzięcia. Zainicjowali kilka akcji, organizując salę komputerową, rzutnik multimedialny i ekran. Powstał dzięki temu miejscowy klub kinowy, a także kilka innych warsztatów, w których uczestniczą mieszkańcy w różnym wieku. A na ścianie bloku, w którym jest ulokowana biblioteka, na zamówienie mieszkańców street-artyści namalowali portret Tarasa Szewczenki. Zainspirowane tą inicjatywą władze miejskie uruchomiły program „Biblioteki bliżej ludzi”, przekształcając biblioteki, zwłaszcza na oddalonych osiedlach, w otwarte przestrzenie, w tak zwane trzecie miejsca ${ }^{12}$. Inny, bardziej złożony projekt powstał w 2014 roku z inicjatywy grupy Jota pod na-

${ }^{11}$ http://bettersykhiv.org/ [dostęp: 1 lutego 2016].

12 „The Third Place”, termin określający miejsce w przestrzeni publicznej, które oddziela środowisko domowe i miejsce pracy. Por. R. Oldengurg, The Great Good Place, New York 1989. 
zwą „Pierwszy festiwal sąsiadów na Podzamczu we Lwowie”13. Główny jego cel to zjednoczenie mieszkańców dzielnicy. Projekt miał rozbudowany program przygotowawczy: spotkanie „Adresy naszych wspomnien”” w ramach pracowni miejskiej (przez ostanie kilka lat organizowanej wspólnie przez Urząd Miejski i Deutsche Gesellschaft für Internationale Zusammenarbeit (GIZ) GmbH) ${ }^{14}$, tygodniowy obóz artystyczny dla dzieci, kulinarne spotkania „Smak Podzamcza”, pokazy filmów na otwartym powietrzu. Główne wydarzenie festiwalowe odbyło się na podwórku szkoły i trwało dwa dni, w ciągu których można było uczestniczyć w prowadzonych przez mieszkańców warsztatach, przygotowanych przez studentów kulturoznawstwa wycieczkach po dzielnicy, koncertach różnych zespołów, wspólnych poczęstunkach. Grupa inicjatorów na każdym etapie starała się nawiązać kontakty z mieszkańcami i włączyć ich do przygotowań. Sformowała się niewielka grupa miejscowych rezydentek, które podtrzymują wzajemne kontakty oraz próbują już samodzielnie bronić swoich interesów.

Forma festiwalu jest bardzo popularna we współczesnych działaniach miejskich. Pozwala ona realizować partycypacyjne projekty nawet w państwie z ograniczoną demokracją, jak na przykład Białoruś. Warto odwołać się tu do odbywającego się w Mińsku Festiwalu na Gruszewce ${ }^{15}$ w 2014 roku. Był on szczególny właśnie dlatego, że angażował mieszkańców w oddolne inicjatywy już od początku przygotowań, od pierwszych etapów: powstawania pomysłów, zbierania funduszy, organizowania imprez. Koniecznym warunkiem realizacji wspomnianego projektu było wpisanie go w państwowe obchody święta 1 Maja. Innym interesującym przykładem ilustrującym podejmowany temat może być projekt realizowany w 2015 roku przez białoruskich aktywistów z autonomicznej grupy architektów Buldożer w ramach „Mińskiej platformy urbanistycznej”"16 na jednym z podwórek Mińska. Wymyślony jako warsztat projektowania i budowania placów zabaw, ale też wspólnej przestrzeni, projekt ten miał pomóc w odpowiedzi na pytanie, jak niewielka, jednak rozciągnięta w czasie architektoniczna interwencja w przestrzeń podwórka wspólnego dla kilku domów mieszkalnych oddziałuje na zachodzące w nim procesy społeczne. Skrupulatnie dokumentowany warsztat był pouczający dla inicjatorów i mieszkańców, bo w procesie jego realizacji ujawniły się osobliwości struktury społecznej mieszkańców (podział na grupy konfrontacyjne odbył się według zamiarów wykorzystania wspólnej przestrzeni: dla piesków albo dzieci), metody konfrontacji (pisanie skarg do władz i milicji albo uczestniczenie w debatach publicznych) oraz sposoby i motywacja uczestnictwa we wspólnym przedsięwzięciu (dofinansowanie projektu lub uczestniczenie w pracach budowlanych). Projekt odkrył też wspólny poradzieckim krajom

\footnotetext{
13 http://iotastory.com/ [dostęp: 14 lutego 2016].

14 Więcej o tym projekcie można znaleźć na stronie internetowej www.maisterniamista.org.ua [dostęp: 14 lutego 2016].

15 Strona internetowa dzielnicy z reportażem o festiwalu: http://www.grushevka.by/novosti-rajona/37-festival-na-grushevke-fotootchet.html [dostęp: 14 lutego 2016].

16 http://urbanist.by/ [dostęp: 14 lutego 2016].
} 
zespół problemów, jak na przykład brak aktywnej wspólnoty związanej z konkretnym miejscem czy rozwiniętych i zwyczajowych praktyk dialogu i współdziałania. Konflikt między mieszkańcami, wynikający z interwencji aktywistów miejskich, nie tylko okazał się przeszkodą w realizacji projektu, lecz także obnażył inne możliwości mobilizacyjne ludzi (przeważnie pionowe: zwrócenie się ze skargami do władz itp.). Taka reakcja potwierdza oczywiście tezę o społeczności miast poradzieckich funkcjonujących jak różnorodne getta, zamknięte z powodu swej ekonomicznej słabości i wywłaszczenia. Jednak inicjatorom projektu udało się stworzyć tymczasową przestrzeń publiczną przez produkcję wiedzy (podczas treningów i spotkań), dyskursu (w czasie debat publicznych) i środowiska materialnego (opracowanie projektu polifunkcjonalnego placu zabaw i jego realizacja).

Krótki ogląd kilku przykładów aktywizmu miejskiego na Ukrainie i Białorusi chciałabym wykorzystać do zastanowienia się nad pytaniem, jak współczesne praktyki aktywizmu miejskiego w tych krajach oddziałują na pojmowanie kultury, jeśli potraktować tę kategorię bardziej ogólnie. Aktywizacja i niemal błyskawiczne rozprzestrzenianie się aktywizmu obywatelskiego, w tym praktyk uczestnictwa w kulturze, zwłaszcza po wydarzeniach rewolucji godności na Ukrainie, dają podstawę do zastanowienia się nad zmianą w myśleniu o kulturze. Obiegowa w edukacji klisza przedstawiająca kulturę jako „całokształt wszystkich materialnych i duchowych wartości stworzonych przez człowieka w ciągu całej historii”" ${ }^{17}$ i prowadząca przede wszystkim do ekskluzywnego traktowania kultury jako obszaru tradycji i duchowości traci już chyba swoją dominującą pozycję. W jej miejscu natomiast kształtuje się pogląd ugruntowany w innych schematach myślowych, które spróbuję określić, odpowiadając na kilka pytań.

„Gdzie kultura jest tworzona”? Miejscem kultury w tym ujęciu jest przestrzeń społeczna (w tym przypadku zwłaszcza w mieście) jako generator sensów i złożony węzeł komunikacyjny działający na kilku różnych poziomach, jako osobliwy krajobraz kulturowy ze złożoną strukturą palimpsestową. Jego funkcjonowanie zapewniają ważne ekonomiczne, społeczne i właśnie kulturowe czynniki, takie jak: własność prywatna i społeczna, sieć wspólnot lokalnych, która tworzy podstawę społeczeństwa obywatelskiego, wartości dialogu, otwartości i solidarności. W związku z tym również sama kategoria kultury się zmieniła i ujmowana jest jako środowisko, a także proces, w którym ważniejsze są nie poszczególne obiekty czy instytucje, lecz nieustannie zmieniające się relacje między nimi ${ }^{18}$ oraz ich użytkownikami, między członkami wspólnot i urzędnikami, między twórcami i aktywistami itp.

17 Zob. na przykład B.M. Шейко, Ю.П. Богуцький, Е.В. Германова де Діас, Культурологія: навч. посіб, Київ 2012, s. 5.

${ }^{18} \mathrm{Z}$ łatwością da się tu rozpoznać postrukturalistyczne podejście do kultury. Bezpośredniego powiązania chyba szukać tu nie warto, chociaż trudno też zaprzeczyć interesującym oddziaływaniom tych koncepcji już na poziomie społecznym, w zakresie działań miejskich. Genezę aktywizmu miejskiego wyjaśnić można też, wychodząc od prac wspomnianego na początku Lefebvre'a, a także od badań z kręgu szkoły z Birmingham. 
„Kim są twórcy kultury i jej bohaterowie”? Status twórcy nie jest już ekskluzywny, wyjątkowy i nabiera cech pospolitych, to znaczy, że każdy w miarę swoich zdolności, umiejętności komunikowania i preferencji czy wartości może być twórcą dóbr kulturowych. Natomiast bohaterami ${ }^{19}$ okazują się mieszkańcy miasta wychodzący ze swoich gett i poszukujący dialogu oraz współpracy. Jeżeli spróbować przedstawić uogólniony portret miejskiego aktywisty, to najczęściej będzie to osoba w wieku 20-35 lat, pochodząca z tzw. klasy kreatywnej, profesjonalnie związana z kulturą, edukacją, nauką. Osoba spędzająca swój czas na tworzeniu dóbr społecznych, nieoczekująca żadnych finansowych korzyści. Mieszkaniec/ mieszkanka uświadamiający sobie „prawo do miasta” i poczuwający się do odpowiedzialności za nie. Dlatego aktywiści zajmujący się rozwiązaniem problemów miejskich wyrażają siebie poprzez organizację wydarzeń kulturowych. Ważne jest dla nich przekazywanie i obrona swego systemu wartości.

„Jakie polityki określają praktyki kulturowe”? Jeżeli patrzeć na praktyki kulturowe przez pryzmat podmiotu działającego i przedmiotu czy przestrzeni, do której te działania są zwrócone, to można zauważyć, że są one kształtowane na podstawie wspomnianego wspólnego systemu wartości. Związane z nim polityki, oparte na inkluzywności, przyjęciu „prawa do miasta”, na solidarności i sprawiedliwości, dialogu i tolerancji innego w jego różnorodności, wpisują się światopoglądowo w paradygmat liberalizmu. Na Ukrainie i Białorusi to nie ideologie jednak są ważne, lecz raczej pragmatyczne i funkcjonalne podejście. W tych krajach praktyki miejskiego aktywizmu organizowane są raczej poza ideowymi założeniami, sięgającymi intelektualnych prądów lewicowych w jak najszerszym rozumieniu. Taka „ślepota na ideologię" związana jest z postkolonialnym „wypieraniem” spuścizny komunistycznej oraz ostrożnością, by nie być z nią skojarzonym. $\mathrm{Na}$ Ukrainie wyraźna staje się tendencja do odbierania aktywizmu miejskiego jako zalążka społeczeństwa obywatelskiego albo też jako przejaw nowej „posthipsterskiej" burżuazji - eklektycznej mieszanki zachodnich ruchów młodzieżowych ostatniego półwiecza, włącznie z ideologiami ,postępowej konsumpcji w stylu high-tech" 20 . Potwierdzenia tej dość kontrowersyjnej tezy można szukać w zewnętrznych i wewnętrznych konfliktach ruchów miejskich, których głównym źródłem okazuje się przede wszystkim walka o język reprezentujący pewien system wartości, ale również orientację na pewien typ komunikowania się.

${ }^{19}$ Wykorzystanie pojęcia „bohater kulturowy” jest tu oczywiście metaforą odsyłającą przede wszystkim do ujęcia Lévi-Straussa, który widzi w bohaterze swoistego mediatora przezwyciężającego podstawowe antynomie kulturowe (zob. C. Lévi-Strauss, Antropologia strukturalna, przeł. K. Pomian, Warszawa 2009).

${ }^{20}$ Według ukraińskiego dziennikarza i filozofa Andrija Bondarenki na Ukrainie „dobra konsumpcja” jest kwintesencją wszystkich ideologii zachodnich i aktualnie jest główną siłą napędową postępowych sił i ruchów obywatelskich. W kontekście aktywizmu miejskiego ta formuła brzmi: „dobre środowisko dla dobrej konsumpcji”. 
„Jakimi językami kultura przemawia”? Można stwierdzić, że najczęściej mamy do czynienia z konfrontacją między odmiennymi językami. Jeden z nich jest wpisany w hierarchię społeczną, wykorzystuje tradycję jako mechanizm powielania schematów działania władzy i podporządkowania, dyskursu zagrożenia i wrogości, powołuje się na autorytet dominujących oraz uznaje jeden możliwy system wartości ${ }^{21}$. Natomiast inny język zorientowany jest na ustanowienie i utrzymywanie relacji poziomych, na reprezentację tego, co zmarginalizowane, otwarty na dialog, na poszukiwanie wspólnych punktów odniesienia w zakresie doświadczenia codziennego, manifestujący wielość możliwych pozycji. Te dwie skrajne strategie retoryczne rzadko występują w stanie czystym, przeważnie są realizowane w złożonych konstrukcjach, tworzą różne kontaminacje. Podczas dyskusji publicznych w relacjach poziomych często spotykane są odniesienia do różnych wzorców estetycznych, które nie dają się pogodzić. Jednocześnie w polemikach każda ze stron podejmuje próby odwoływania się do zespołu nieproblematycznych (na razie) wartości i celów (na przykład dobre warunki dla dzieci, pokój, bezpieczeństwo, zadbana i czysta wspólna przestrzeń). Takie poszukiwania zawsze pozostawiają szanse na trwanie negocjacji i pogodzenie skrajnych pozycji. A kultura zyskuje na wielogłosowości rozwijającej się w otwartej przestrzeni dialogu, tworzonej przez różnorodne strategie retoryczne odsyłające do różnych wartości.

Oczywiście te pytania i odpowiedzi nie są wystarczające i wyczerpujące, jednak pozwalają ująć kulturę na przykład jako „przekształcone, nacechowane wartościami i znaczeniami środowisko społeczne - wytwarzane przez jednostki i grupy, które również oplata zmienna i różnorodna sieć wartości i znaczeń"22. To nagromadzenie różnych kultur grupowych (czyli subkultur) cechuje się mozaikowym wręcz zróżnicowaniem, zmiennością i zdolnością do łączenia w ramach doraźnych całości. Mimo nierzadko przeciwstawnych tendencji działających wewnątrz kultury, tworzące ją grupy pozostają jednak w sieci wzajemnych, dynamicznych i na ogół złożonych relacji. „Każda część składowa określonej kultury, poprzez swoje działanie (lub jego brak) w sposób intencjonalny lub całkowicie

${ }^{21}$ Kwestia walki o język i przyjęcie lub odrzucenie pewnych modeli komunikowania w zakresie kształtowania nowej kultury obywatelskiej jest oczywiście osobnym ważnym tematem. Jak się okazało, przezwyciężenie schematów retorycznych ukształtowanych w ramach dyskursu totalitarnego jest jednym z najpoważniejszych wyzwań, przed którym stoją społeczeństwa krajów poradzieckich. $Z$ tego powodu chciałabym tylko wspomnieć interesującą analizę nowomowy Michała Głowińskiego, pochodzącą jeszcze z 1978 roku (M. Głowiński, Nowomowa po polsku, Warszawa 1991), i wykład rosyjskiego badacza Nikołaja Wachtina Język radziecki i jego wyniki (https:// www.youtube.com/watch?v=mckIchYAi34 [dostęp: 14 lutego 2016]) wygłoszony w 2015 roku, w którym autor wyjaśnia „syndrom niemoty publicznej”, powszechne praktykowanie „mowy zrytualizowanej ”, dzięki której utrzymuje się dyskurs totalitarny, po transformacji ustrojowej przejęty przez określone partie polityczne w krajach Europy Środkowej i Wschodniej.

22 B. Fatyga, Kultura, [hasło w:] Stownik teorii żywej kultury, http://ozkultura.pl/wpis/112/5 [dostęp: 14 lutego 2016]. 
przypadkowy uczestniczy w kulturze, głównie z racji tego, iż jest ona powiązana z innymi elementami różnymi relacjami" ${ }^{23}$. Uświadomienie takiego ujmowania kultury otwiera wiele możliwości, które aktywizm miejski jako jeden z rodzajów uczestniczenia w kulturze może wykorzystać, i wyzwań, którym musi sprostować. Współdziałanie z przestrzenią miejską nie tylko staje się obszarem twórczości ograniczonej specjalnymi miejscami lub osobliwymi twórcami, lecz także przenika codzienność i przez różne praktyki umacnia rozumienie uczestnictwa w kulturze jako procesu stawania się kultury. Aktywista jest nosicielem i promotorem zmian, nadając środowisku dynamiczny i otwarty charakter. Rozwój oddolnej ,iwentowej” infrastruktury zakłada inny poziom funkcjonowania sztuki i inne sposoby komunikowania, burzące mury kulturowych gett. Jednocześnie rewitalizacyjne działania aktywistów bez wyraźnych celów i zasad mogą ograniczyć się tylko do marketingu miejsca przechwyconego przez władze lub/i inwestorów. Jednorazowe, ograniczone finansowymi i organizacyjnymi możliwościami interwencje w wybrane miejsca i środowiska narażają się na jałowość i krótkie trwanie, nie radząc sobie z rutyną codzienności, z inercją przyzwyczajeń mieszkańców, którym nie zawsze udaje się wyjście z własnej strefy komfortu i przyjęcie na siebie odpowiedzialności. Przy tym aktywiści często są odbierani jako interwenci zagrażający istniejącemu status quo albo nawet wyznawanemu systemowi wartości, prowokując w ten sposób manifestację języka wrogości i odwoływania się do autorytetu hierarchii. Wyzwania te mają mocny potencjał kreatywny wytwarzający nowe modele komunikowania i działania społecznego, a także cechują się traktowaniem kultury jako nieustającego „,procesu recepcji i interpretacji dóbr kulturowych, jak również procesu ich wybierania, komentowania, poświęcania im czasu, ich zmieniania, niszczenia, konserwowania, uzyskiwania o nich informacji i dostępu do nich, używania jako pretekstu do spotkania i nawiązywania kontaktów z innymi ludźmi" ${ }^{24}$. Wydaje się, że w takim podejściu jest wielka szansa na przyszłość.

${ }^{23}$ M. Krajewski, W kierunku relacyjnej koncepcji uczestnictwa $w$ kulturze, „Kultura i Społeczeństwo" 2013, nr 1, s. 50.

${ }^{24} \mathrm{Ta}$ definicja pochodzi z portalu internetowego http://www.tworzeniekultury.pl/strona-glowna.html, który przedstawia projekty działań oddolnych połączonych z bardzo interesującymi refleksjami nad uczestnictwem w kulturze. 


\title{
Urban activism and changes in the recognition of culture (for example, Ukraine and Belarus)
}

\author{
Abstract
}

In the article the activity of urban activists is presented based on various examples, together with their main subjects and methods of operation. The problems occuring in this field in Ukraine and Belarus are also discussed. At the same time on the basis of this analysis, the author tries to answer a number of questions about the place and the creators of culture, of urban policies and rhetorical strategies defining culture and, finally, how the modern practices of urban activism impact the recognition of culture as a whole.

Keywords: urban activism, urbanism, urban policies, participation, local communities, culture of participation, city

\section{Bibliografia}

A Map of Urban Initiatives, https://kumu.io/UrbanMap/co-urbanism [dostęp: 10 listopada 2015].

Balokaite R., Post-Soviet Transitions of the Planned Socialist Towns: Visaginas, Lithuania, „Studies of Transition States and Societies"2, 2010, $\mathrm{nr} 2$.

Bernhardt Ch., Planning Urbanization and Urban Growth in the Socialist Period: The Case of East German New Towns, 1945-1989, „Journal of Urban History” 32, 2000.

Fatyga B., Kultura, [hasło w:] Stownik teorii żywej kultury, http://ozkultura.pl/wpis/112/5 [dostęp: 14 lutego 2016].

Finogenov A., Modern Russia and Urban-Planning Reality of Post-Soviet City, http://urbanica.spb. ru/?page_id=645\&lang=en [dostęp: 15 listopada 2015].

Głowiński M., Nowomowa po polsku, Warszawa 1991.

http://bettersykhiv.org/ [dostęp: 1 lutego 2016].

http://iotastory.com/ [dostęp: 14 lutego 2016].

http://laimikis.lt [dostęp: 15 listopada 2015].

http://spilnorivne.tumblr.com [dostęp: 15 listopada 2015].

http://studway.com.ua/urban-iniciativi [dostęp: 15 listopada 2015].

http://urbanist.by/ [dostęp: 14 lutego 2016].

http://urbanist.by/ [dostęp: 15 listopada 2015].

http://www.grushevka.by/novosti-rajona/37-festival-na-grushevke-fotootchet.html [dostęp: 14 lutego 2016].

http://www.trotuar.lviv.ua/ [dostęp: 10 listopada 2015].

Krajewski M., W kierunku relacyjnej koncepcji uczestnictwa w kulturze, „Kultura i Społeczeństwo” 2013, nr 1.

Lefebvre H., Prawo do miasta, „Praktyka Teoretyczna” 2012, nr 5, http:// www.praktykateoretyczna.pl/PT_nr5_2012_Logika_sensu/14.Lefebvre. pdf [dostęp: 15 listopada 2015].

Lévi-Strauss C., Antropologia strukturalna, przeł. K. Pomian, Warszawa 2009.

Oldengurg R., The Great Good Place, New York 1989.

The post-socialist city: Urban form and space transformations in Central and Eastern Europe after Socialism, red. K. Stanilov, Dordecht 2007. 
Robinson J., Soviet city: identity and community development, https://www.researchgate.net/publication/255616367_THE_POSTSOVIET_CITY_IDENTITY_AND_COMMUNITY_DEVELOPMENT [dostęp: 15 listopada 2015].

Wachtin N., Język radziecki i jego wyniki, https:/www.youtube.com/watch?v=mckIchYAi34 [dostęp: 14 lutego 2016].

www.maisterniamista.org.ua [dostęp: 14 lutego 2016].

Культурологія: навч. Посіб, В.М. Шейко, Ю.П. Богуцький, Е.В. Германова де Діас, Київ 2012. Місто й оновлення. Урбаністичні студіi, Представництво Фонду ім. Гайнріха Бьолля в Україні, red. С. Шліпченко, В. Тимінський, А. Макаренко, Л. Малес, І. Тищенко, Київ 2013.

Тыминский В., Постсоветский город: проблемы и принципы проектирования будущего = Postsoviet city: problems and principles of future's creating, [w:] Совершенствование организации дорожного движения и перевозок пассажиров и грузов, red. Ф. Романюк, Минск 2014. 